\title{
The Effect of Work-Based Learning Model in Improving the Competence Students of Diploma III Nursing
}

\author{
Taufiq Nur Muftiyanto \\ Doctor Program in Education \\ Sebelas Maret University \\ Surakarta, Indonesia \\ Taufiq.mufti@student.uns.ac.id \\ Sri Haryati \\ Teacher Training and Education \\ Sebelas Maret University \\ Surakarta, Indonesia
}

\author{
Muhammad Akhyar \\ Doctor Program in Education \\ Sebelas Maret University \\ Surakarta, Indonesia
}

\author{
Munawir Yusuf \\ Doctor Program in Education Sebelas \\ Maret University \\ Surakarta, Indonesia
}

\begin{abstract}
The competence of a nurse is something that is displayed thoroughly by a nurse in providing professional services to clients, including knowledge, skills, and considerations required in practical situations. The impact of students' lack of competence will lead to patient safety incidents. To increase competence in their field and experience in the industrial world, an effective learning model is needed, namely work-based learning. The purpose of this study was to determine the effect of the work-based learning model on the competence of nursing diploma students. The method used in this research is descriptive qualitative with data collection techniques in the form of questionnaires, interviews, and documentation. The results of this study indicate that the work-based learning model affects improving the competence of Diploma III Nursing students at ITS PKU Muhammadiyah Surakarta.
\end{abstract}

Keywords-Work-Based Learning Model, Nursing Competence, Diploma III Vocational Education

\section{INTRODUCTION}

Education has a major role in providing quality Human Resources (HR) and should be the answer for society, especially modern society. Vocational education has a major role in planning and creating professional and productive middle-level human resources [1]. One of the efforts to improve the quality and relevance of education is to develop vocational or vocational schools because the workforce that is much needed is at the level of technical school graduates [2]. As stated by Balogh (1969) that vocational schools can overcome problems in developing countries which emphasize that as a determinant of prosperity and socio-economic progress, education must be technical, vocational, and democratic [3]. Thus the provision of vocational schools to produce the necessary skills is very important.

Law Number 20 of 2003 concerning the National Education System mandates that "vocational education is education that prepares students to work in certain fields. Vocational education (vocational) prepares students to master skills or skills certain as a provision for work. This statement is following Bennett's opinion that vocational education includes all forms of technical and vocational education and is organized by various forms of educational institutions, both by the government and by the community, informal and nonformal forms, to help the community to obtain education and training based on the principle of lifelong learning [4]. From a socio-economic perspective, vocational/vocational education is economic education, because it is derived from the needs of the labor market, giving a derivative to economic strength. Vocational education is education to prepares students to enter the workforce. Vocational education must be designed so that graduates have skills, abilities, knowledge, attitudes, and work habits that are following the needs of the world of work. Including in the world of work in the Health sector.

Universities in the field of Health play an important role in producing competent and quality health workers by providing theory and practice including cognitive, affective, and psychomotor through lecture materials with the hope that students can think highly. The quality of health services is closely related to the quality of professional nurses. Professional nursing requires nursing services to be provided with competencies that meet standards and 
pay attention to ethical and moral rules [5]. Nursing as a profession also has a body of knowledge that is different from other professions, is altruistic, has a professional forum, has standards and professional ethics, accountability, autonomy, and peerage [5]. In Indonesia, the nursing profession is important in helping to improve individual health degrees and public health degrees [6].

Nurses as one of the main components of providing health services to the community have an important role because they are directly related to their competence and education [6]. The results of the research by the Directorate of Nursing and PPNI regarding the activities of nurses are known that more than $75 \%$ of all health service activities are nursing service activities. General problems that occur in nursing services are the lack of nurses who have higher education, the number of less friendly nurses, and the lack of patience of nurses in dealing with patients. Syah (2018) argues that the emphasis on developing and fostering higher nursing education is more directed at efforts to improve the quality of education so that graduates demonstrate a professional attitude, master nursing knowledge, and master nursing professional skills [7]. Currently, in Indonesia, there are many nursing education institutions whose educational processes run with great variations, and the quality control system of the education delivery process has not been fully implemented, so the quality or competence of graduates is very diverse. Competency testing is a process of measuring the knowledge, skills, and behavior of students at universities that organize nursing study programs.

The problem that occurs in Indonesia in nursing education is that the regulation on the establishment and implementation of nursing education is still not firm and clear so that there are many nursing education institutions whose quality is still in doubt. In addition, there is no standardization in the implementation of competency tests, so the results achieved are of varying quality. In addition, education level does not have much effect on the competence, recognition, and welfare of nurses in the workplace in providing nursing care. Whereas nursing education is an important process that must be passed by every nurse. The competence of nursing students consists of three parts, namely, the abilities, knowledge, and attitudes possessed by these students [8]. One of the patient safety standards that have been set by JCI (Joint Commission International) is the target of implementing patient safety in hospitals which includes correct patient identification, increasing effective communication, using drugs safely, ensuring the right location, procedure, and right patient, reducing risk. infection, and identify the patient's risk of falling [9].

The results of research conducted by Iswati (2015) show that students have insufficient knowledge about patient safety, including the correct patient identification process by $32 \%$, effective communication by $61 \%$, correct medication increase by $59 \%$, the certainty of the right location, procedure and patient [10]. by $74 \%$, reducing the risk of infection by $86 \%$, and reducing the risk of falling by $43 \%$. Meanwhile, another study conducted by Puspita Sari (2015) showed that students' knowledge of patient safety was far from $100 \%$ [11]. The impact of students' lack of competence regarding patient safety will lead to patient safety incidents, such as giving medicine to the wrong patient, patients falling out of bed taking actions that are not following procedures, and so on [12]. During the implementation of practice in the room, clinical supervisors and nurses more closely monitor and influence students who are practicing.

This problem also occurs in students of the nursing vocational education program for students of the Institute of Health and Science Technology (ITS) PKU Muhammadiyah Surakarta. The lack of competency achievement by students is one of them in the Indonesian Nurses Competency Exam (UKNI). The average UKNI graduation rate is still very low. In 2019 the DIII ITS PKU Muhammadiyah Surakarta study program inaugurated 246 graduates, but only 117 graduates of the DIII Nursing study program who pocketed a certificate of work internship experience at the Hospital [13]. The success of DIII Nursing students of ITS PKU Muhammadiyah Surakarta in learning can be known through evaluation, the aim is to find out the achievements of students after the teaching and learning process takes place. Problems that are often found in practical activities are always related to learning. The results of the author's interviews with several lecturers showed that the DIII Nursing students of ITS PKU Muhammadiyah Surakarta did not yet have sufficient ability to apply the nursing skills acquired during education. Students already know but in skills and at the end of each practice they are still lacking.

The selection of learning forms and methods to find the right strategy so that students can fulfill their learning achievements, by developing active interactions between students, lecturers, and learning resources [14]. Through industrial practice, the Diploma III program is one of the field courses intended to equip students to have work experience in the industry to develop their vocational knowledge and skills and to empower students in their future learning and career responsibilities. The purpose of industrial practice is that students can increase their knowledge of science and technology through fieldwork activities in the industry following their field of expertise.

The application of Work-Based Learning (WBL) in vocational education in the world has been around for a long time, both at the secondary and higher education levels. The application of WBL in 
vocational learning is based on the philosophy of improving the quality, relevance, and efficiency of vocational learning for the world of work [15]. The partnership between vocational education institutions and industry in the implementation of learning is a necessity. The Ministry of National Education (2003) suggests that work-based learning is a learning strategy that allows students to use the workplace context to study school-based learning materials and how these materials are reused at work or in various activities combined with subject matter for the benefit of students. WBL is also defined as an active learning process to make advancements in work competencies with direct and contextual experience in the world of work. WBL is carried out in the form of work-based training as a process of developing work skills, work knowledge, work attitudes, work morals in the world of work.

So that students are competent in their fields and experienced in the industrial world, an effective learning model is needed to improve the skills and quality of students [16]. Various theories and contemporary research in workplace-based teaching and learning support the praxis of vocational education, especially those related to contextual learning. Recent research results conclude that the use of the Workplace-Based Learning Approach (PBTK) in education has a positive effect on achievement, motivation, and continuing education [17]. Research conducted by (Lynch \& Harnish, 1998) shows a correlation between outcomes and the impact of graduates with the learning structures provided by schools and industry as on-the-job experiences [18]. work. When program objectives, curricula, and workplace-based experiences are designed and implemented with adequate staff support and properly evaluated, the program will have a positive impact. Therefore, the authors are interested in researching on how the influence of Work-Based Learning (WBL) in improving the competence of DIII Nursing students at the Institute of Science and Health Technology (ITS) PKU Muhammadiyah Surakarta.

\section{Methods}

This study uses a qualitative descriptive approach that aims to describe the effect of Work-Based Learning in improving the competence of DIII Nursing students at ITS PKU Muhammadiyah Surakarta. The data sources in this study were the head of the DIII Nursing study program, staff, lecturers, and students of the DIII Nursing study program by purposive random sampling. Data collection techniques in this study are, using questionnaires, interviews, documentation, and observation. The data analysis technique uses Miles \& Huberman (1992) which consists of three plots [19]. First, reduction. Data reduction is defined as the process of selecting, focusing on simplifying, abstracting, and transforming rough data that emerges from written notes in the field.
Data reduction takes place continuously as long as a qualitative research-oriented project takes place. The second presentation is a structured collection of information that provides the possibility of drawing conclusions and taking action. Third, concluding is an activity of a complete configuration. Conclusions were also verified during the study.

\section{RESULTS AND DISCUSSION}

\section{A. Work-Based Learning}

Work-Based Learning (WBL) is a learning approach that utilizes the workplace to structure experiences gained in the workplace, contribute to social, academic, and career development of learning and become a supplement in learning activities. The learning experience in the workplace is applied, refined, expanded in learning both on campus and in the workplace. With WBL, learning develops attitudes, knowledge, enlightenment skills, behaviors, habits, and relationships from experiences in both places and allows learning related to real work activities [18]. The quality of vocational education outcomes both in terms of processes and products is strongly influenced by the learning approach used in conducting vocational education. WBL is used as terminology in various countries for programs at schools or colleges to gain experience from the world of work.

Work-Based Learning (WBL) is becoming a trend in education because it affects learning satisfaction and increases the role of tutors in learning [20]. WBL is learning at the tertiary level which includes learning for work (job placement), learning in the workplace (eg in-house training programs), and learning through work (eg related to work accredited by universities) [21]. WBL is used as terminology in various countries for programs in schools/colleges to gain experience from the world of work and for youth to prepare for the school-to-work transition (http://www.iowaworkforce.org/files/wlg02. pdf) and to learn the realities of the world of work/work and be prepared to make the right choices in work [22].

Boud \& Solomon (2001) describe that WBL programs typically have the following characteristics: (1) a partnership between an external organization and an educational institution that is stipulated by contract; (2) learners are involved as workers (by making negotiated to learn plans); (3) learning programs are formulated from the needs of the workplace and participants, and not only from the academic curriculum that has been prepared; (4) the learning program is adapted individually for each learner according to their previous educational/work/training experience; (5) learning programs as integrated projects/tasks at the place of work; (6) learning outcomes are measured by educational institutions [23]. 
Many things must be considered in the implementation of this WBL, starting from the curriculum, assessment and facilities, and infrastructure. For the curriculum itself, the structure and design of learning must encourage and support experimental learning. In addition, it must also enable students to learn from work experience/practice. Furthermore, in the assessment, there must be direct physical evidence. In this case, each student is assessed individually regarding grades, additional points, and deficiencies in a competency. It is also necessary to have a separate point in practice if there are students who can solve the problem. Then the assessment strategy should make students active to demonstrate both academic learning outcomes with related practical work. And for the facilities and infrastructure must be following those in the industry. the school must also have industrial cooperation for activities/workplaces that support the development of student's abilities.

Furthermore (Sudira, 2012) suggests that WBL requires a learning process that can produce workers who have the competence and ability to deal with technological changes, use technology as learning support, and intelligently apply learning skills to develop other contextual intelligence [24].

\section{B. Obstacles to the implementation of Work-Based Learning}

Obstacles to the implementation of Work-Based Learning (WBL) at ITS PKU Muhammadiyah Surakarta, came from internal sources according to explanations from the lecturer. The first is the problem of students who cannot be on time in choosing an internship place. So the campus has given the final limit for students to register at the internship and have received a reply letter/time agreement. But in reality, until the time limit specified, students have not been able to provide a reply letter/agreement at that time.

The campus has reminded many times of students who are not disciplined but still, students have not been able to submit the letter. Furthermore, problems that occur from internal campuses are about supervisors and certificates. The campus in evaluating the Field Work Practice makes certificates for students. The certificate is made based on the value of the internship and is also approved by the internship. However, after the certificate has been made by the campus and then it remains only to be ratified by the internship site through the supervisor, here there is a problem. The supervising lecturer did not immediately ask for a signature and stamp of the internship place after the certificate was finished, but the time was postponed. Until last year the certificate could not be issued after one semester after the implementation of the fieldwork practice. And if the time is too long, the person in charge of the fieldwork practice directly comes to the internship place to ask for the signature and stamp. Things like this should be used as an evaluation so that later it doesn't happen again.

Constraints in the implementation of WBL originate from outside the campus. According to the explanation of the ITS PKU Muhammadiyah lecturer, there were several obstacles to implementing WBL that came from the internship place. The first is that the internship place limits students in carrying out fieldwork practices. This kind of limitation is very important considering the conditions of the internship place and also the comfort in fieldwork practices. However, in some places, the internship limiting students to fieldwork varies from year to year. This makes students do not understand how many students are recommended to practice fieldwork at the internship place. The next problem is about the distance between the internship place and the student's house which is too far. As happened at ITS PKU Muhammadiyah, students are willing and have registered for fieldwork practices at a clinic. However, the campus urges the students to rethink their wishes. So that there will be no problems in the future. And also lecturers are easier at monitoring and guiding students.

\section{Competence of DIII Nursing ITS students}

Nursing as a profession requires nursing services to be provided professionally by nurses with competencies that meet standards and pay attention to ethical and moral rules so that the community is protected because they receive quality nursing services and care [6]. Simamora (2009) argues that nursing graduates are required to master the knowledge, attitudes, and skills following the demands of the profession [25]. Therefore, to create graduates who have the knowledge, skills, and attitudes of professional nursing who can manage simple basic and applied nursing research activities and use the results of research and developments in science and technology (IPTEK) to improve the quality and reach of nursing services/care. is the purpose of the vocational education of nursing and nurses profession.

Clinical competence is the ability to be involved in problem-solving, apply theory to practice, and demonstrate psychomotor abilities. Clinical competence includes:

- experiences that have a positive effect on the preparation of new nurses in clinical practice.

- as new nurses, so that they with their expertise can be more successful in their achievements.

- educators and leaders must have an understanding of the relationship between performance-based on clinical competence.

Students must have a close relationship with clinical instructors in solving competency problems because it is important to ensure that they are ready and able to go directly into practice to accompany 
professional nurses. Nurse competency standards reflect the competencies that nurses must possess to provide professional nursing care.

Nursing student competencies include main competencies, supporting competencies, and other competencies. These competencies can be described as follows:

\section{1) Main Competencies}

- Able to provide nursing care in general cases holistically and continuously in promotive, preventive, curative, and rehabilitative client systems in simulated cases.

- Able to conduct health education and health promotion as part of primary, secondary, and tertiary prevention efforts in the client system.

- Able to apply the principle of patient safety in nursing practice.

- Able to do nursing problem solving through scientific approach steps.

- Able to analyze the application of the concept of an organization, leadership, and management in the management of nursing care.

\section{2) Supporting Competencies}

- Able to use the principles of effective communication techniques and collaboration of the health team in simulation cases.

- Able to identify a variety of entrepreneurial efforts characterized by innovation in the field of nursing.

- Able to apply information technology in the field of nursing.

- Able to use Indonesian and English in the context of nursing.

- Able to plan for disaster management (disaster) and disaster mitigation in case of simulation.

3) Other Competencies

- Able to display professional behavior in nursing.

- Able to apply transcultural concepts in providing culturally sensitive nursing care.

- Able to identify complementary therapies in providing nursing care.

\section{The influence of Work-Based Learning in improving the competence of DIII Nursing students.}

Development of learning in the implementation of vocational education must continue to be carried out by the managers so that the quality of graduates is in line with the demands of the job market. The challenges of the world of work with increasingly high work competencies along with technological advances and workplace dynamics require vocational education institutions to be able to anticipate and deal with changes that occur by utilizing various existing capabilities. Various indications about the quality of education are the background to the problems in the implementation of Vocational Education Diploma III Nursing with the approach Work-Based LearningBased (WBL)or WorkplaceTeaching and Learning (PBTK). The Implementation work-based learning model is a WBL program model whose implementation system is standard, the completeness of training facilities has met the minimum standard requirements for training competencies, instructors and field supervisors are available, the organization of human resources is good, the environmental situation and work safety are safe and adequate, and other supporting tools for complete workplace learning. All are fulfilled at the/training center training centers in various health industries that are used as trial partners. Thus, this WBL implementation model can be used as an example or reference for other WBL organizing programs.

Recent research results conclude that the use of the Workplace-Based Learning Approach (PBTK) or WBL in education has a positive effect on achievement, motivation, and continuing education [17]. Research and evaluation studies at WBL show a correlation between the outcomes and impact of graduates and the learning structures that schools and industry provide in the workplace experience. When program objectives, curricula, and workplace-based experiences are designed and implemented with adequate staff support and properly evaluated, the program will have a positive impact [18].

Based on interviews with lecturers of the ITS PKU Muhammadiyah Surakarta Diploma III Nursing Study Program, information was obtained that the implementation of academic program learning in Nursing DIII Prodi is designed to prepare nursing staff who can become leaders in their fields and can bring changes in the realization of a quality nursing profession. The theory learning process is carried out in the classroom as well as in hospitals/clinics by applying various models and learning methods that refer to the latest curriculum. To strengthen nursing skills, students are provided with lab skills using the method of bedside teaching in the form of small groups, so that all students are ensured to be skilled before being deployed in a real setting in hospitals or the community.

Apart from the results of interviews, and analysis of the influence of the WBL model on improving the competence of DIII students also carried out through the results of observations and documentation of the competence of students of the Diploma III Nursing study program at ITS PKU Muhammadiyah Surakarta 
showing that student competence is low. Based on the results of the analysis carried out by researchers, in general, students participated in fieldwork practice learning activities quite well. Learning using the method of bedside teaching in the form of small groups makes students less active. To activate students, the efforts made by lecturers are to provide guidelines in the form of learning modules used by students in field practical work. Researchers see many less active students. Based on the results of these observations, students must be encouraged to be active in learning practical fieldwork. For this reason, a learning model is needed that has an approach that encourages active students and can foster an enthusiasm for learning in students of the Diploma III Nursing study program at ITS PKU Muhammadiyah Surakarta. Based on this analysis, the WBL learning model was applied to nursing DIII students.

In this study, the Work-Based Learning model has a positive effect on increasing the competence of DIII Nursing students at ITS PKU Muhammadiyah Surakarta. This can be seen from the knowledge of the theoretical concepts of patient nursing care, clinical skills procedures and effective use of technology, professional attitude, mental readiness to work, independence, and being ability to apply concepts \& principles of nursing ethics, communication in professional nursing practice. These results have a more significant mean when compared to before the use of the WBL learning model. This is very important because so far the field/industry experience has only emphasized cognitive. Skills and affective aspects of professional attitudes, mental readiness for work, and independence with this model also significantly increased. These results indicate that the WBL model has a positive effect on improving the quality of student competence. In line with various studies on the application of EBL programs in several countries and several schools or colleges [26]. Although there are several obstacles in its implementation, the WBL model has a positive effect on student competence.

\section{CONCLUSION}

The success of the WBL model is determined by several interrelated factors, namely: students, supervisors, supervisors in the industry (instructors, mentors, supervisors), management, facilities (training, dormitories, training climate, etc.). The preparation of the WBL manual/guideline is one of the efforts so that there is a standard reference in the implementation of work-based learning that is determined by the approach (including strategymethod-tactics). Various models of WBL that are devoted to the implementation of WBL for vocational education (Diploma III), adapted to the characteristics and substance of the field of industrial cooperation partners.

\section{REFERENCES}

[1] I. G. Sudirtha, R. P. Ariani, M. D. Anggendari, \& L. Masdarini. Penyiapan Sumber Daya Manusia Di Bidang Vokasional Melalui Pengembangan Program Studi Pendidikan Kejuruan Strata Dua. Proceeding Semnasvoktek, 2(8), 2017. 276-283.

[2] S. Soenarto, M. M. Amin, \& K. Kumaidi. Evaluasi implementasi kebijakan Sekolah Menengah Kejuruan program 4 tahun dalam meningkatkan employability lulusan. Jurnal Penelitian Dan Evaluasi Pendidikan, 21(2), 2017. 215-227. https://doi.org/10.21831/pep.v21i2.17076

[3] T. Balogh. Education and agrarian progress in developing countries. In K. Hufne \& J. Naumann (Eds.), Economics of Education in transition. Stuttgart: Ernst Klett. 1969.

[4] I. Hanafi, Pendidikan teknik dan vokasional (menggali pengalaman sukses institusi Bi-National di negeri jiran dari konsep hingga implementasi). Yogyakarta: Deepublish. 2014.

[5] T. R. P. Lestari. Upaya Menghasilkan Tenaga Perawat Berkualitas Nursing Education: Effort To Produce Quality Nurses Personnel. Pusat Pengkajian, Pengolahan Data Dan Informasi, 2014. 1-10.

[6] T. R. P. Lestari. Harapan atas profesi keperawatan di indonesia. Kajian, 79(1), 2014. 51-68.

[7] D. Z. R. Syah. Hubungan Prestasi Akademik Dan Faktor Eksternal Dengan Kelulusan Uji Kompetensi Mahasiswa Keperawatan Stikes Jenderal Achmad Yani Yogyakarta. Jurnal Keperawatan Muhammadiyah, 2(2). 2018. https://doi.org/10.30651/jkm.v2i2.985

[8] S. Stevanin, V. Bressan, G. Bulfone, A. Zanini, A. Dante, \& A. Palese, Knowledge and competence with patient safety as perceived by nursing students: The findings of a crosssectional study. Nurse Education Today, 35(8), 2015. 926934. https://doi.org/10.1016/j.nedt.2015.04.002

[9] Joint Commission International. Joint commission international accreditation standards for hospitals including academic medical center hospitals. 2014.

[10] I. Iswati. Pengetahuan Dan Penerapan Sasaran Keselamatan Pasien Pada Mahasiswa Semester 6 Di Akademi Keperawatan Adi Husada Surabaya. Adi Husada Nursing Journal, 1(1), 2015. 6. https://doi.org/10.37036/ahnj.v1i1.3

[11] D. W. P. Sari. Potret Pelaksanaan Patient Safety Mahasiswa Profesi Ners. Nurscope: Jurnal Penelitian Dan Pemikiran Ilmiah Keperawatan, 1(2), 2015. https://doi.org/10.30659/nurscope.1.2.1-11

[12] S. Riada. Gambaran Kompetensi Mahasiswa Keperawatan terhadap Pelaksanaan Sasaran Keselamatan Pasien di RSUD Ungaran Kabupaten Semarang. Jurnal Jurusan Keperawatan. 2016.

[13] Admin. Wisuda ITS PKU Muhammadiyah Surakarta. 2019. https://itspku.ac.id/2019/08/31/wisuda-its-pkumuhammadiyah-surakarta/

[14] A. Junaidi. Panduan Penyusunan Kurikulum Pendidikan Tinggi Di Era Industri 4.0 Untuk Mendukung Merdeka Belajar-Kampus Merdeka. Jakarta: Direktorat Jenderal Pendidikan Tinggi Kementerian Pendidikan dan Kebudayaan. 2020.

[15] P. Sudira. Metodologi Pembelajaran Vocational: Inovasi, Teori dan Praksis. Yogyakarta: UNY Press. 2018.

[16] L. Chapman. Improving patient care through work-based learning. Nursing Standard (Royal College of Nursing (Great Britain): 1987), 20(41), $2006 . \quad 41-45$. https://doi.org/10.7748/ns2006.06.20.41.41.c6549

[17] T. Bailey, and D. Merritt. School-to-Work for the College Bound. 1997.

[18] R. L. Lynch, \& D. Harnish. Preparing pre-service teachers education students to use workbased strategies to improve instruction. In Contextual teaching and learning: Preparing teachers to enchance student success in the workplace and 
beyond. Columbus: OH: ERIC Dearinghouse on Adult, Career, and Vocational Education. 1998.

[19] Miles, \& Huberman. Analisis Data Kualitatif. Universitas Indonesia Press. 1992.

[20] V. Woltering, A. Herrler, K. Spitzer, \& C. Spreckelsen. Blended learning positively affects students' satisfaction and the role of the tutor in the problem-based learning process: Results of a mixed-method evaluation. Advances in Health Sciences Education, 14(5), 2009. 725-738. https://doi.org/10.1007/s10459-009-9154-6

[21] D. Gray. Assessment Series. January 2014.

[22] K. A. Paris, \& S. A. Mason. Planning and implementing youth apprenticeship and work-based learning. Wisconsin: Center on Education and Work, Univer-sity of Wisconsin. 1995.
[23] D. Boud, \& N. Solomon. Work-based learning a new higher education? London : SRHE and Open University Press. 2001.

[24] P. Sudira. Filosofi Dan Teori Pendidikan Vokasi Dan Kejuruan. Yogyakarta: UNY Press. 2012.

[25] H. Simamora. Manajemen Sumber Daya Manusia. Jakarta: Gramedia. 2009.

[26] D. D. Bragg, R. E. Hamm, \& K. A. Trinkle. Work-based learning in two-year colleges in the united states, National Center for Research in Vocational Education, Berkeley, CA. ERIC No: EDIII78446. 